\title{
The Role of Context in Shaping Students Entrepreneurial Intentions
}

\author{
Rukundo $^{1^{*}}$ S. Friend, Cyeze ${ }^{2}$, M. Emmanuel, Mwambari ${ }^{3}$, Faustin
}

${ }^{1}$ School of Administrative science- Management, Université Laval, Canada and School of Economics and Business studies, Kigali Independent University (ULK), Kigali Campus, Rwanda.

${ }^{2}$ School of Social Sciences, Kigali Independent University ULK, Gisenyi Campus, Rwanda.

${ }^{3}$ Ministry of labor, Rwanda and School of Economics and Bsusiness studies, Kigali Independent University (ULK)

Kigali Campus, Rwanda.

friendrukundo@gmail.com

Abstract:

Purpose: The purpose of this study is to investigate the impact of contextual variables on entrepreneurial intentions.

Design/Methodology/Approach: We searched for articles in the EBSCO, ProQuest, and Web of Science databases. To maintain quality standards, we select only empirical impact studies published in peer reviewed journal. We passed through all articles which worked on context variables as antecedents in entrepreneurship research (Entrepreneurship Theory and Practice, Journal of Business Venturing, Journal of Small Business Management, Small Business Economics, Journal of Applied Psychology, International Journal of Gender and Entrepreneurship, International Journal of Entrepreneurship and Small Business, and Gender, Work \& Organization).

Findings : The findings indicate that few research were conducted on the entrepreneurship education, culture, institutions, socio- economic variables, locus of control, demographic, and technology. The findings strongly support that the context play a significant role in configuration of entrepreneurial intentions.

\section{Research Limitations}

Theoretical Implications: While many studies on entrepreneurship education were conducted, but none of the article worked on the role of context pay in configuration of entrepreneurial intentions using a systematic review.

Research Perspective: There is a need of conducting more research on the impact of contextual factors on entrepreneurial intentions comparing developed and developing countries.

Keywords: Entrepreneurial intentions, entrepreneurship education, culture, institution, socio- economical, locus of control, demographic and technology.

\section{INTRODUCTION}

The publication of Shapiro's seminal works some 30 years ago marks the point at which the literature on entrepreneurial intentions begins its current period of rapid growth. Soon after that, some independent contributions emerge in the field of entrepreneurship, as more authors begin to recognize the potential value 
of the intention approach. A shift in the focus of entrepreneurship research toward a process view undoubtedly contributes to this development (Fayolle, A., \& Liñán, F. 2014, p 663).

Empirical research results reveal significant differences in terms of attitudes and intention levels of students who take part in entrepreneurship and those who do not. Nonetheless, whether and how a generalization of those results to a range of settings may occur remains a pending question (Fayolle, A., \& Liñán, F. 2014, p 663).

Entrepreneurship is playing important roles in the long-term economic development and competitiveness of a region. (Leung et al. 2012, p. 1). It has also become an economic panacea, seen as generating employment and economic prosperity in both developing and developed countries (Packham et al. 2010, p. 568). There is a general acceptance of the increasing importance of entrepreneurs in the creation of jobs in the new economy

(Martinez et al. 2007, p.99).

Fayolle, A., \& Liñán, F. (2014, p 664) recently argue that there is growing recognition in entrepreneurship research that economic behavior can be better understood within its historical, temporal, institutional, spatial and social context." Thus, a strong need exists to examine the heterogeneous aspect of context (Zahra \& Wright, 2011). Some research sets out to understand entrepreneurial intention in different countries (Liñán, Fernández, \& Romero, 2013; Moriano, Gorgievski, Laguna, Stephan, \& Zarafshani, 2012). Nevertheless, although countries are one sub-dimension of the spatial context, the design of research could also assess the influence of communities, industrial districts and clusters (other sub-dimensions of the spatial context) on entrepreneurial intention formation (Liñán, Urbano, \& Guerrero, 2011).

This topic was taken as the fourth proposal of new ideas and research perspectives on entrepreneurial intentions (Fayolle, A., \& Liñán, F. 2014, p. 664). The main theoretical contribution of this work is to make the systematic review of the role played by context in the formation of entrepreneurial intentions.

To evaluate whether these concerns are justified, we conducted a systematic review of contextual factors of entrepreneurial intentions. The objectives of our study are: (1) to provide an overview of the context and its role on entrepreneurial intentions, and (2) to provide recommendations for the design of future impact studies in entrepreneurial intention.

\section{LITERATURE REVIEW}

Mohamed et al. (2012) states that entrepreneurs are developed through multiple factors and profile traits. However, not all of the traits and factors are compulsory in order to create an entrepreneur. He explains that attitudes towards entrepreneurship depend on exogenous factors such as demographic traits, skills, culture and social and financial support. He reports that those who found a positive view of their family's business experience perceived starting a business as both desirable and feasible. They also found that an experience during childhood of frequently relocating had a positive effect on perceived autonomy and attitude towards self-employment. He also indicates that a family business has a role to play in enhancing the development of entrepreneurship among family members. On the other hand, the educational background plays a vital role on creating entrepreneurial skills. It means those with the technical background can leverage a mere idea into a potentially successful process "technical visionaries".

Mueller and Thomas (2001) argue that culture in general may condition the potential for entrepreneurship, with individualistic cultures tending to reinforce and reward independent action more than collectivistic 
cultures (Mueller and Thomas, 2001). The context of culture and economic development has been explored by a great number of research studies, with the main finding being that the developing world must be regarded as a diverse range of countries with unique characteristics that require separate analyses (Bernhofer, L., \& Han, Z. 2014, p. 127).

Entrepreneurship can be characterized as a step-wise process which is influenced by both exogenous as well as endogenous factors, such as the existence of a business friendly environment, the availability of the required factor endowments, the ability to acquire desired resources, and the ability to implement and manage the business concept (Mohamed et al. 2012, p. 608).

Hofstede (2001) distinguished between the following five cultural dimensions: power distance, individuality, masculinity, uncertainty avoidance, and long/short-term orientation. Because risk-orientation is one of the major predictors of entrepreneurial behaviour, it makes sense to compare the four countries under study on uncertainty avoidance. Uncertainty avoidance is "the extent to which the members of a culture feel threatened by uncertain or unknown situations" (Hofstede, 2001, p.161). It can be assumed that in countries scoring low on uncertainty avoidance, people are more willing to take risks. In countries high on uncertainty avoidance, one could expect a greater fear of failure, and thus a lower willingness to take risks. ( Shinnar, R. S., Giacomin, O., \& Janssen, F, 2012, and Schlaegel, C., He, X., \& Engle, R. L. 2013).

The most recent large-scale cultural study - the GLOBE study (House et al., 2004) found Iran and India to be among the countries with the highest (in-group) collectivism (measured as societal practices). Poland and Spain still exhibited rather high in-group collectivism practices, while Germany and the Netherlands were among the most individualistic countries.

Strong cultural values such as collectivism, femininity and the absence of entrepreneurial vision which characterised the managerial behaviours of entrepreneurs. Giacomin et al. (2011) explain that an individual's entrepreneurial intentions can be shaped by his or her perceptions of barriers to business start-up, cultural values, and the environment in which he or she is located. Lüthje and Franke (2003) see entrepreneurial intentions as related to cultural values and shaped by perceived barriers to creation as well as the infrastructure in place to support entrepreneurs (St-Jean, 2014, Shinnar, R. S., Giacomin, O., \& Janssen, F, 2012, Schlaegel, C., He, X., \& Engle, R. L.2013)

Solesvik, M. Z. (2013, p. 258) suggest that career choice research should concentrate not only on cognitive-person variables alone, but needs to be considered together with environmental variables (e.g. social, cultural, and economic variables) which influence cognitive-person variables. Entrepreneurial intention of university students in various cultural contexts indicated that the encouragement from university environment affects the entrepreneurial confidence of university students (Ghazali et al. 2013, p. 86).

Entrepreneurship education in general seeks to create an entrepreneurial mindset and training concerning necessary skills and knowledge to help students turn their ideas into action. In the context of graduate entrepreneurship in developing countries, Ertuna and Gurel (2011) confirmed that higher education generally tends to increase entrepreneurial intentions and other studies have found a positive impact of entrepreneurship education on attitudes towards an entrepreneurial career. Nevertheless, entrepreneurship education must meet different needs in developing countries and research that focuses attention on these differences and the overall roles and effects of entrepreneurship education is still rare (Nabi and Linan, 2011). 
Entrepreneurship education refers to the scope of curricular lectures or courses that primarily aim at sensitizing and qualifying students for an entrepreneurial career (Walter et al. 2013, p. 178). Entrepreneurship education has been proposed as one key influence on self-employment intentions (Walter, S. G., \& Dohse, D. 2012, p. 810).

Education for sustainable development aims to challenge and empower individuals to promote sustainable development across all disciplines and at all levels of society (Lourenco et al. 2013, p. 843). The entrepreneurial support model considers predominantly the impact of contextual factors on entrepreneurial intention. In the model, entrepreneurial intention is taken as a function of educational, relational, and structural supports. The results of the survey show that educational and structural support factors affect the entrepreneurial intention of students (Jorge et al. 2012, p. 412). The dominant entrepreneurship education program in secondary schools and colleges in the US and Europe is the Junior Achievement Young Enterprise student mini-company (SMC) program. Oosterbeek et al. 2010, p. 443).

Within the area of knowledge there appears a likely influence of human capital such as education and work experience upon the ability to identify and exploit new opportunities (Hannah Noke \& Martin Binks 2012, p. 894). Entrepreneurship education consists of "any pedagogical [program] or process of education for entrepreneurial attitudes and skills" (Tae Jun Bae et al. 2014, p. 219). The research literature we highlighted suggests the need for structured programs to support aspiring and actual entrepreneurs in developing not only entrepreneurial intentions but also realistic perceptions of feasibility (Barbosa et al. 2008, p. 422). Although entrepreneurship education is recognized to be important there have been relatively few empirical studies of its impact, distinct from that of general education, on perceptions of entrepreneurship and EI (Zhang et al.2014, p. 624).

Institutional (or neo-institutional) theory emphasises the effects of the social environment on organisations and individuals, which is presumed to impose constraints on organisations, affecting how they look-their structures-and what they do-their practices. Institutional theory emphasises social rules, expectations, norms, and values as primary factors pressuring organisations and individuals to conform. Institutions are defined as "cognitive, normative, and regulative structures that provide stability and meaning to social behaviour". It can therefore be posited that barriers to entrepreneurship in different countries will differ due to the diverse institutional conditions (Iakovleva et al. 2014, p. 120). The empirical study of Luthje and Franke (2003) has shown that perception of external factors (perceived contextual barriers and support) directly affect the entrepreneurial intention of students.

Zainuddin et al. (2010) highlighted the importance of contextual factors in the university environment such as facilitating the occurrence and the intensity of entrepreneurial behaviours, and the orientations and behaviours of students influenced by internal and external factors.

Providing occupational choices are influenced by future earning and employment opportunities we conclude that university quality should at least indirectly influence the likelihood that graduates will become entrepreneurs (Daghbashyan, Z., \& Harsman, B. 2014, p. 732).

It is argued that only certain teaching methods (i.e. traineeships and field learning) are more successful than others at preparing students for an entrepreneurial career. Therefore, if entrepreneurship academicians lack pedagogical knowledge and skills, it might affect the delivery of learning experiences to the students. This concern was confirmed, it was found that academicians' definitions of entrepreneurship were influenced by their backgrounds and by the number of years they had worked in the business sector. Therefore, if lecturers lacked 
or had no experience in enterprise ownership and management, they were unable to precisely illustrate the entrepreneurship environment; and worst still, they would provide the wrong perceptions of entrepreneurship to students. Thus, the level of perceived feasibility and desirability transferred to students from academicians will be less substantial (Zainuddin et al. 2010, p. 513).

Experiential learning actually occurs when students engage in some activity, reflect upon the activity, derive insight from the analysis, and incorporate the result through a change in understanding (Sherman et al. 2008, p. 31).

As a building, the creative industries are shadowed by 'roof' consisting of intellectual, business, and government group. Intellectual group in this case is an institution of higher education, which has knowledge of entrepreneurship and other supporting knowledge that is supposed to be a driver and facilitator for the intellectual development of the creative industries actor (Rahayu, A. Y. S., \& Fitriati, R. 2013, p. 100).

Characterized as an informal institution, culture has been described as "the interactive aggregate of common characteristics that influence a human group's response to its environment” (Schlaegel, 2013, p. 599).

A recent study by Watson (2013a) proposes that entrepreneurs, like other human beings, continuously face different circumstances and contexts, and need to come up with creative solutions for the problems they face. In this sense, Entrepreneurial Context (EC) is a "situated creativity" or ability that any kind of person (not just entrepreneurs) will mobilize in the entrepreneurial contexts that they encounter. In other words, once situated in entrepreneurial contexts, people's general creativity will manifest in different ways and thus produce different effects than in non-entrepreneurial contexts. General creativity is present in all populations, but EC is the "situated" and contextualized creative ability acquired and developed through entrepreneurial processes and experiences (Watson, 2013a).

External environmental conditions can influence firm formation, survival and development. Institutional (or neo-institutional) theory emphasises the effects of the social environment on organisations and individuals, which is presumed to impose constraints on organisations, affecting how they look-their structures-and what they do-their practices. Institutional theory emphasises social rules, expectations, norms, and values as primary factors pressuring organisations and individuals to conform (Iakovleva et al. 2014, p. 120).

Iakovleva et al. (2014) state that regulative structures refer to formal laws, rules and regulations. In relation to entrepreneurship, it was pointed out earlier in this article that while developed countries have established and good working mechanisms for business support, including governmental grants and programmes, easy registration of business, and available banking services, the situation is much less favourable in Russia and Romania.

Social influence includes the influence of family members, instructors, advisors, friends, and community. In education, primary social influences include a variety of social support, role models, instrumental assistance, and financial resources. Prior research findings indicated the more the positive social influence, the stronger the behavioral intention (Chen, L. 2013, p. 236). Lourenco et al. (2013) note that initially, environmental and social initiatives were perceived as imposing legal and ethical burdens on businesses. Social Network Theory suggests resources obtained from the individual's social network heavily influence the decision to embark on an entrepreneurial start-up process (Ozgen, E., \& Minsky, B. D. 2013, p. 46). 
Researchers have shown the importance of the social status of entrepreneurial activities and situations in the participant's environment. Particularly, empirical evidence of the relationship between the parental role model and preference for a self-employment career has been repeatedly reported (Scott and Twomey, 1988; Matthews and Moser, 1995). Pruett, M. (2012) noted a negative relationship between the perceived feasibility of entrepreneurship and the social significance of failure. The central focus of social enterprises is its mission, a core effort that concentrates on redressing a social problem (Schlee et al. 2013, p. 128).

Smith, I. H., \& Woodworth, W. P. (2012) states that one of the most powerful pedagogical devices for developing social entrepreneurs is to help and encourage students to engage in a social entrepreneurship project. Whereas readings, lectures, cases, and the biography assignment help students define social entrepreneurship as a social category, identify prototypical members, learn vicariously from models, and receive encouragement, the group project gives them the opportunity to actively engage in social entrepreneurship mastery experiences-which helps solidify their social identity and self-efficacy.

Locus of control relates to an individual's perceptions of the ability to influence events in one's life. The concept is cognitive and control-based and can be affected, for example, by life experiences. It also covers a variety of situations and can be distinguished by internal and external locus of control (I-E). An 'internal' believes that one has control over life by having influence over outcomes through ability, effort, or skills. 'Externals,' on the other hand, believe that external forces determine outcomes (Bernhofer, L., \& Han, Z. 2014, p. 129).

Ajzen, (2002) states that founding entrepreneurship research generally suggests that high levels of internal locus of control are an important entrepreneurial characteristic, since it is viewed as a prerequisite for action. An individual, for example, might perceive an entrepreneurial opportunity as desirable and feasible (in terms of self-efficacy) but may not actually act and setup a new company.

The number of human capital and demographic variables significantly influencing motivational factors is notably different (Liñán, F., \& Chen, Y. 2009, p. 607). Haus et al. (2013) emphasized the importance of contexts for entrepreneurship to understand when, how and why people become entrepreneurs. In particular, social contexts (i.e. traditions and norms) are important as they help to explain gender specific behavior in entrepreneurship by determining gender roles.

Although the number of women in self-employment is increasing throughout the world, they are still outnumbered by male entrepreneurs (Dabic 2012, p. 319). In general, women-owned businesses are of smaller size than male-owned businesses, women possess less business experience than men, their businesses are usually undercapitalized, and their business growth is slower (Johansen, V. 2013, p. 218).

Studies from the Western, industrialized countries suggest that male and female entrepreneurs tend to share more similarities than differences. It was found that both males and females had a high value for self-respect, freedom, and accomplishments. The opposite results have been found in other studies, where female participation rates were consistently lower than men - women were found to be less likely as men to start businesses and much less likely to start high-growth, high-profit firms (Majumdar, S., \& Varadarajan, D. 2013, p. 280).

Experiential learning actually occurs when students engage in some activity, reflect upon the activity, derive insight from the analysis, and incorporate the result through a change in understanding (Sherman et al. 2008, p. 31). 
In the IT entrepreneurial context, CSE is related to innovation self-efficacy, which refers to entrepreneurs' technology and business innovations. In fact, IT entrepreneurs must manage innovation and risk in technology (e.g., exploring new technologies and technology usages) and business (e.g., creating new business models or business processes with technology) and exercise leadership in both technology and business management. In other words, IT entrepreneurs often are technology-business innovators (Chen, L. 2013, p. 236).

Evolutionary psychologists as well as agency scholars note both the advantages and disadvantages that might accrue in publically owned firms with a high level of family involvement. Some guidance to address the ambiguity of what happens in public firms with family involvement can be found in the literature related to the resource-based view (RBV) of the firm. Family firms are, by definition, a collective endeavor. Embedding a firm in a collectivistic culture, that accepts, endorses, and legitimizes it, is more likely to lead to improved performance. Embedding a family business in an individualistic environment, however, is contradictory and leads to the issues (O'Boyle et al. 2012, p. 5).

To get a clearer picture of the quality of the existing literature of contextual factors on entrepreneurial intentions, it is therefore indispensable to analyze the applied empirical and theoretical research. Our study aims to show the role that the context play in configuration of entrepreneurial intentions among university students.

\section{MeTHOdology}

The purpose of this article is to analyze the role of context in shaping students entrepreneurial intentions with a systematic literature review (SLR). "Systematic literature reviews are recognized methods for conducting evidence based policy" (Pittaway and Cope, 2007: 5). SLRs are different compared to "narrative reviews" as an open reporting style is used in the same terms as it would be for empirical research. Furthermore, SLRs utilize methods to assess the quality of the empirical data (Pittaway and Cope, 2007).

The document analysis is expected to enable the researcher to access data at his convenient time, to obtain unobtrusive information, obtain data that are thoughtful in that the informants have given attention to compiling them. This instrument will be used to collect data mainly from empirical journal articles and conceptual articles (Lussier, R. N 2011, p. 43).

The time period covered by the research took place over the past decade, from January 2005 to the effective time of exploration or December 2015. The search for articles was conducted from 01/02/2015 to 10/02/ 2015. To the extent that any of the analyzed theories were referenced as such in-used databases, it has not been possible to resort to the use of the thesaurus to refine the relevance of the lexical field.

We searched for articles in the EBSCO, ProQuest, and Web of Science databases. To maintain quality standards, we select only empirical impact studies published in peer reviewed journal.

In a first stage, we built a database of entrepreneurial context studies published in English. For the selection of papers, we conducted a M. Lorz, S. Mueller \& T. Volery comprehensive and systematic keyword search using the following combinations of terms: (1) "entrepreneurship education" and "context", (2) "entrepreneurship education" and "intentions", (3) "entrepreneurial intentions "and "context”, (4) "entrepreneurship", “Education”" and "intention". A first preliminary research based on the theories set forth above, and according to the taxonomy, has helped identify a shortlist of 307 articles. As shown in Table 1, our final database includes 59 context of entrepreneurial intentions' studies. 


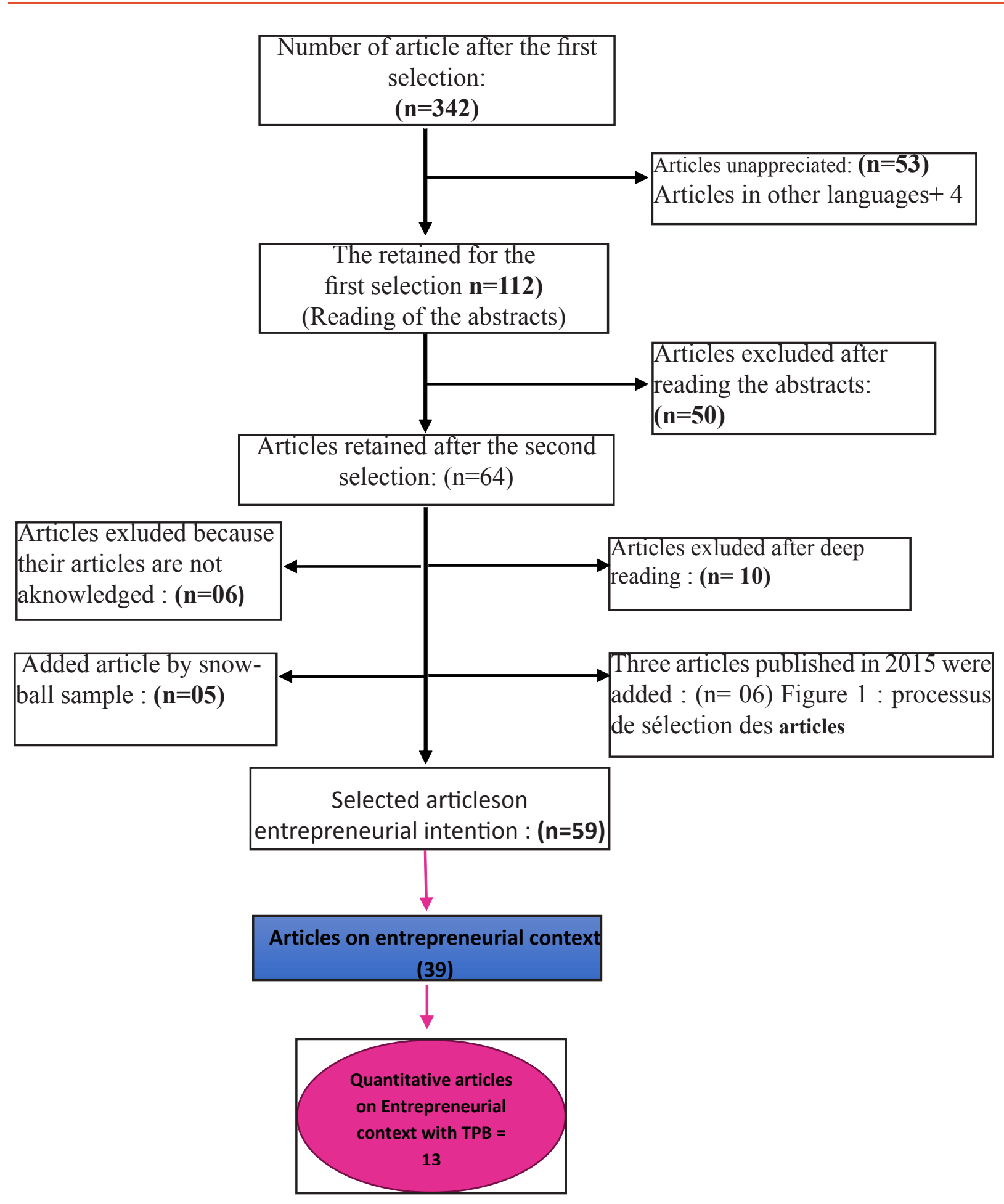

Figure1. processes of selecting articles 
We then develop an analytical framework which includes four major categories: key variables, research design, data collection, and data analysis.

For all studies in our sample, the role of context is independent variable.

With regard to the research design we distinguish between qualitative, quantitative, and mixed methods, a decision that depends on the research objective and influences the generalizability of the results. We also analyze whether or not the research was theory-driven. Theory-driven research is an essential attribute of high-quality research.

Building on Yang et al. (2006), we analyzed three criteria regarding sampling: the sample source, sampling technique, and the sample size. Sample source refers to the geographic scope of the sample. Since cultural differences might influence research results, the sample source influences the external validity and the generalizability of the study. In terms of sampling techniques, random samples usually provide an adequate approximation of the population and prevent sampling bias (Rauch and Frese, 2006). In addition, large sample sizes can minimize sampling errors and increase the generalizability of research findings (Lazerwitz, 1968).

\section{RESULTS}

The evolution of the literature on entrepreneurial intention is a prime example of the successful integration of theories from a neighboring field into the study of entrepreneurship. In this particular case, the theories shifting to the entrepreneurship field belong to the area of social psychology, namely cognitive psychology. The speed of this integration process is remarkable, as publication of the first contributions from the field of psychology almost coincides with the early developments of the concept of entrepreneurial intention in the field of entrepreneurship. This phenomenon is true of, for instance, the concept of self-efficacy and the theory of planned behavior (Ajzen, 1991) and its antecedents (Fayolle, A., \& Liñán, F. 2014, p 663).

Forming an intention to develop an entrepreneurial career is the first step in the often long process of venture creation (Iakovleva et al. 2011, p. 355). There are so many works on entrepreneurial education but few research were conducted on the entrepreneurial context as indicated in the table 1

Table1. The identified articles on entrepreneurial context

\begin{tabular}{|c|c|c|c|c|c|c|c|c|c|}
\hline \multirow[t]{2}{*}{$\mathrm{N}$} & \multicolumn{2}{|l|}{ Authors } & \multicolumn{2}{|l|}{ Publication } & \multirow[t]{2}{*}{ Context Variables } & \multirow[t]{2}{*}{ Theory } & \multirow{2}{*}{$\begin{array}{l}\text { Coefficients impact of } \\
\text { contextual variable to } \\
\text { entrepreneurial intention }\end{array}$} & \multicolumn{2}{|c|}{ Sapling } \\
\hline & Names & $\begin{array}{l}\text { No. of } \\
\text { authorts }\end{array}$ & Journal & Year & & & & Size & country \\
\hline 1 & $\begin{array}{l}\text { Moriano, J. A., } \\
\text { Gorgievski, M., } \\
\text { Laguna, M., } \\
\text { Stephan, U., \& } \\
\text { Zarafshani, K. } \\
(2012) .\end{array}$ & 4 & $\begin{array}{l}\text { Journal of Career } \\
\text { Development, } \\
39(2), 162-185\end{array}$ & 2012 & $\begin{array}{l}\text { Gender, age, } \\
\text { employment } \\
\text { status, and major }\end{array}$ & TPB & $\begin{array}{l}\text { w2 } \\
(179 \text { df) } 1 / 4786.23, \mathrm{p}< \\
.001 ; \text { CFI } 1 \frac{1}{4} .93 ; \text { NNFI } \\
1 / 4.90 \\
\text { RMSEA } 1 / 4.06 .\end{array}$ & 1,074 & $\begin{array}{l}\text { Germany, } \\
\text { India, Iran, } \\
\text { Poland, } \\
\text { Spain, and } \\
\text { the } \\
\text { Netherlands }\end{array}$ \\
\hline 2 & $\begin{array}{l}\text { Fayolle, A., Gailly, } \\
\text { B., \& Lassas- } \\
\text { Clerc, N. (2006). }\end{array}$ & 2 & \begin{tabular}{|l|} 
Journal of \\
European Industrial \\
Training, 30(9), \\
$701-720$. \\
\end{tabular} & 2006 & $\begin{array}{l}\text { Entrepreneurship } \\
\text { education } \\
\text { programmes } \\
\text { (EEP) } \\
\end{array}$ & TPB & $\begin{array}{l}\text { Measures before the EEP } \\
1.14 \\
\text { Measures after the EEP } \\
1.4\end{array}$ & 20 & France \\
\hline
\end{tabular}




\section{American Research Journal of Humanities and Social Science (ARJHSS)}

\begin{tabular}{|c|c|c|c|c|c|c|c|c|c|}
\hline 3 & $\begin{array}{l}\text { Wurthmann, K. } \\
\text { (2014). }\end{array}$ & 1 & $\begin{array}{l}\text { International } \\
\text { Entrepreneurship } \\
\text { and Management } \\
\text { Journal, 10(4), } \\
691-711 .\end{array}$ & 2014 & $\begin{array}{l}\text { Demographics } \\
\text { (Age, Male) \& } \\
\text { prior exposure }\end{array}$ & TPB & $\begin{array}{l}\text { Age: } 0.129 \dagger, 0.147^{*}, \\
0.123 \dagger, 0.133^{*} \\
\text { Male: } 0.016,0.045, \\
-0.085,-0.059 \\
\text { Prior exposure to starting } \\
\text { a business } 0.142^{*}, 0.119 \dagger, \\
0.037,0.035\end{array}$ & 314 & USA \\
\hline 4 & $\begin{array}{l}\text { Bernhofer, L., \& } \\
\text { Han, Z }\end{array}$ & 2 & $\begin{array}{l}\text { International } \\
\text { Journal of } \\
\text { Technology } \\
\text { Management, } \\
65(1-2), 125 .\end{array}$ & 2014 & $\begin{array}{l}\text { Background, } \\
\text { Demographics \& } \\
\text { entrepreneurship } \\
\text { education }\end{array}$ & ТРВ & $\begin{array}{l}\text { Gender } 14.132^{* *} \text {, Level } \\
\text { of education } 6.233^{*}, \\
\text { Educational background } \\
140.247^{* *} \text {, Family } \\
\text { business background } \\
239.796^{* *}\end{array}$ & 384 & China \\
\hline 5 & $\begin{array}{l}\text { Liñán F \& } \\
\text { Yi-Wen Chen }\end{array}$ & 2 & Entrepreneurship & 2009 & $\begin{array}{l}\text { Human capital } \\
\text { and other } \\
\text { demographic } \\
\text { variables }\end{array}$ & TPB & $\begin{array}{l}\text { Age } 38623.6323 .104125 \\
23.0882 .97851123 .499 \\
3.080 \\
\text { Gender* } 387.442 .497125 \\
.584 .495512 .477 .500\end{array}$ & 323 & $\begin{array}{l}\text { Spain, } \\
\text { Taiwan }\end{array}$ \\
\hline 6 & $\begin{array}{l}\text { Zainalabidin } \\
\text { Mohamed; Rezai, } \\
\text { Golnaz; Mad } \\
\text { Nasir Shamsudin; } \\
\text { Muhammad Mu'az } \\
\text { Mahmud }\end{array}$ & 4 & $\begin{array}{l}\text { Education \& } \\
\text { Training, }\end{array}$ & 2010 & $\begin{array}{l}\text { Specialised } \\
\text { entrepreneurship } \\
\text { education (SEE) }\end{array}$ & ТРВ & SEE 90.920 & 410 & Malasyia \\
\hline 7 & $\begin{array}{l}\text { Iakovleva, T, Lars } \\
\text { Kolvereid, Ute } \\
\text { Stephan,University } \\
\text { of Sheffield }\end{array}$ & 4 & $\begin{array}{l}\text { Education \& } \\
\text { Training }\end{array}$ & 2011 & $\begin{array}{l}\text { Demographics \& } \\
\text { past- experience, }\end{array}$ & ТPB & $\begin{array}{l}\text { Age } 1 \\
\text { Gender } 0.116 * 1 \\
\text { Previous self-employment } \\
0.239 * 0.142 * 1\end{array}$ & 2,225 & 13 countries \\
\hline 8 & $\begin{array}{l}\text { St-Jean, } \\
\text { Étienne; Nafa, } \\
\text { Aziz; Tremblay, } \\
\text { Maripier; Janssen, } \\
\text { Frank; Baronet, } \\
\text { Jacques; et al.. }\end{array}$ & 6 & $\begin{array}{l}\text { International } \\
\text { Journal of } \\
\text { Entrepreneurship } \\
\text { and Innovation } \\
\text { Management18.2-3 } \\
: 95 .\end{array}$ & 2014 & Demographics & ТРB & $\begin{array}{l}\text { Gendera }-0.228 * * * \\
-0.164 * * *-0.193 * * * \\
-0.178^{* *}-0.188-0.180 \\
\text { Age } 0.217 * * * 0.166 * * * \\
0.176^{* *} 0.165 * * 0.018 \\
0.008\end{array}$ & 1,810 & $\begin{array}{l}\text { Canada, } \\
\text { Belgium, } \\
\text { France, } \\
\text { Algeria }\end{array}$ \\
\hline 9 & $\begin{array}{l}\text { Solesvik, M. Z. } \\
\text { (2013). }\end{array}$ & 1 & $\begin{array}{l}\text { Education \& } \\
\text { Training, 55(3), } \\
253-271 .\end{array}$ & 2013 & $\begin{array}{l}\text { Age } \\
\text { Gender } \\
\text { Parental self- } \\
\text { employment } \\
\text { Education major }\end{array}$ & TPB & $\begin{array}{l}\text { Age } 0.130 .080 .01 \\
\text { Gender } 0.010 .040 .04 \\
\text { Parental self-employment } \\
0.12 * 0.12 * 0.05 \\
\text { Education major } 0.16 * * \\
0.14 * * 0.01\end{array}$ & 321 & $\begin{array}{l}\text { Ukrein } \\
\text { universities }\end{array}$ \\
\hline 10 & $\begin{array}{l}\text { Shinnar, R. S., } \\
\text { Giacomin, O., \& } \\
\text { Janssen, F. }\end{array}$ & 3 & $\begin{array}{l}\text { Entrepreneurship, } \\
\text { 36(3), 465-493. }\end{array}$ & 2012 & Culture & TPB & $\begin{array}{l}\text { Individualism } 43 \\
\text { Uncertainty avoidance } 64 \\
\text { Power distance } 55 \\
\text { Masculinity } 50\end{array}$ & 761 & $\begin{array}{l}24 \\
\text { Countries }\end{array}$ \\
\hline
\end{tabular}

Volume 2 


\begin{tabular}{|c|c|c|c|c|c|c|c|c|c|}
\hline 11 & $\begin{array}{l}\text { Harris, Michael L; } \\
\text { Gibson, Shanan G }\end{array}$ & 2 & $\begin{array}{l}\text { Education \& } \\
\text { Training, 50(7), } \\
568-581\end{array}$ & 2008 & Past- experience & TPB & $\begin{array}{l}\text { Statistically, significant } \\
\text { differences were not found } \\
\text { at the p, } 0.05 \text { level for } \\
\text { Innovation attitudes (mean } \\
\text { of } 7.17 \text { for those who had } \\
\text { owned a small business } \\
\text { versus } 6.88 \text { for those that } \\
\text { had not) and self-esteem } \\
\text { attitudes (mean of } 5.61 \text { for } \\
\text { those who had owned a } \\
\text { small business versus } 5.75 \\
\text { for those who had not). }\end{array}$ & 216 & USA \\
\hline 12 & $\begin{array}{l}\text { Schlaegel, C., He, } \\
\text { X., \& Engle, R. L. } \\
(2013) .\end{array}$ & 3 & $\begin{array}{l}\text { International } \\
\text { Journal of } \\
\text { Management }\end{array}$ & 2013 & $\begin{array}{l}\text { Culture (Power } \\
\text { distance, } \\
\text { Individualism, } \\
\text { Masculinity, } \\
\text { Uncertainty } \\
\text { avoidance) }\end{array}$ & $\begin{array}{l}\text { The } \\
\text { theory of } \\
\text { planned } \\
\text { behaviour }\end{array}$ & $\begin{array}{l}\text { Power distance } .27 \\
\text { Individualism }-.59 \\
\text { Masculinity } .08 \\
\text { Uncertainty avoidance } \\
-.19\end{array}$ & 2063 & 14 countries \\
\hline 13 & $\begin{array}{l}\text { Zhang, Y., } \\
\text { Duysters, G., \& } \\
\text { Cloodt, M. }\end{array}$ & 3 & $\begin{array}{l}\text { International } \\
\text { Entrepreneurship } \\
\text { and Management } \\
\text { Journal, 10(3), } \\
623-641 .\end{array}$ & 2014 & $\begin{array}{l}\text { Entrepreneurship } \\
\text { education, prior } \\
\text { entrepreneurial } \\
\text { exposure }\end{array}$ & TPB & \begin{tabular}{|l} 
Entrepreneurship \\
Education 494.8137652 \\
$.7161799020 .320 .30 *$ \\
$0.27 * 1.00$ \\
(5) Prior Entrepreneurial \\
Exposure 494.2368421 \\
$.2534327-0.51-0.04$ \\
$0.02-0.01-0.021 .00$
\end{tabular} & 494 & China \\
\hline
\end{tabular}

The evolution of the literature on entrepreneurial intention is a prime example of the successful integration of theories from a neighboring field into the study of entrepreneurship. In this particular case, the theories shifting to the entrepreneurship field belong to the area of social psychology, namely cognitive psychology. The speed of this integration process is remarkable, as publication of the first contributions from the field of psychology almost coincides with the early developments of the concept of entrepreneurial intention in the field of entrepreneurship. This phenomenon is true of, for instance, the concept of self-efficacy and the theory of planned behavior (Ajzen, 1991) and its antecedents (Fayolle, A., \& Liñán, F. 2014, p 663).

Forming an intention to develop an entrepreneurial career is the first step in the often long process of venture creation (Iakovleva et al. 2011, p. 355). There are so many works on entrepreneurial education but few research were conducted on the entrepreneurial context as indicated in the table 1

Since main parts of this article are based on the analysis of context factors, the general characteristics and assumptions are briefly introduced. For the first context level, the focus is a combination of culture and economic development. The cultural context can be divided into individualistic and collectivistic societies. Individualistic societies are based on individual contribution, emphasising personal initiative and achievement; in collectivistic cultures, social identity is based on group membership, with group decisions considered superior to individual decisions (Bernhofer, L., \& Han, Z. 2014, p. 127). The culture was taken as the only context which affect the entrepreneurial context yet there are other contextual factors that play the role in entrepreneurial intentions. 


\section{Discussion \& ConCLUSION}

In this article we found that so many researchers worked on entrepreneurship education. The outcome of previous studies have confirmed that entrepreneurship education seeks to prepare people, especially the young, to be responsible, enterprising individuals who become entrepreneurs or entrepreneurial thinkers who contribute to economic development and sustainable communities. It is not based on a textbook course; instead, students are immersed in real life learning experiences where they have an opportunity to take risks, manage the results, and learn from the outcomes. Therefore, entrepreneurship needs to be understood in its widest sense since the personal qualities involved-creativity, initiative, self-confidence, perseverance, self-belief, risk taking and independence - have an importance far beyond the strictly business environment (Vij, V., \& Ball, S. 2009, Ertuna and Gurel 2011, Nabi and Linan, 2011, Walter et al. 2013, Walter, S. G., \& Dohse, D. 2012, Vij, V., \& Ball, S. 2009, Jorge et al. 2012, Oosterbeek et al. 2010, Hannah Noke \& Martin Binks 2012).

Other contextual factors of entrepreneurial intentions which have been developed are discussed below

The context and institution was developed by different researchers. Moriano et al. (2012) argues that culture influences intentions primarily through the influence on the "social" component in the TPB model, that is, subjective norms. Culture is defined as "the collective programming of the mind that distinguishes the members of one group or category of people from another" (Hofstede, 2001, p. 9). National culture can influence the lens through which entrepreneurs perceive opportunities for business start-up, and could function as either an aid or represent significant barriers (Iakovleva et al. 2014, p. 121). While Shinnar et al. (2012) state that national culture consists of the underlying value systems that are specific to a group or society and motivate individuals to behave in certain ways (Bernhofer, L., \& Han, Z. 2014, Thomas 2001, Mueller and Thomas, 2001, Bernhofer, L., \& Han, Z. 2014, Ghazali et al. 2013, . Moriano et al. 2012, Hofstede, 2001, Iakovleva et al. 2014, Shinnar et al. 2012, House et al., 2004, St-Jean 2014, Giacomin et al. 2011, Solesvik, M. Z. 2013).

Not only must the economic and social context be considered when developing entrepreneurship education and training policy, but according to the endogenous theory of growth, economic development is linked with knowledge spill-overs that are localized (Iacobucci, D., \& Micozzi, A. 2012, p. 677). Our conceptual model proposes a direct impact of external factors, such as perceived barriers, financing concern, and perceived opportunity cost on the intention of students toward participating in entrepreneurial activities on campus (Leung et al. 2012, Iacobucci, D., \& Micozzi, A. 2012, Leung et al. 2012, Iakovleva et al. 2014, Chen, L. 2013, p. 236, Lourenco et al. 2013, Ozgen, E., \& Minsky, B. D. 2013, Scott and Twomey, 1988; Matthews and Moser, 1995, Pruett, M. 2012, Schlee et al. 2013, Smith, I. H., \& Woodworth, W. P. 2012). But some other researchers founder that entrepreneurship education does not necessarily influence positively the entrepreneurial intentions (Fayolle, A., Gailly, B., \& Lassas-Clerc, N. 2006).

Fayolleetal.(2006) haveshown theimportance ofinstitutionalvariablessuchasinternal culture, entrepreneurship dedicated structures, resources and mechanisms or institutional strategy towards entrepreneurship. Examples include the availability of funds to help finance venture creation projects by students, support networks for entrepreneurial initiatives (professionals and businesses), entrepreneurship centres, business incubators, a broad supply of entrepreneurship programmes, entrepreneurship institutes and specialized libraries (Iakovleva et al. 2014, Luthje and Franke 2003, Fayolle et al. 2006, Watson 2013a, Lüthje and Franke 2003, Zainuddin et al. 2010, Daghbashyan, Z., \& Harsman, B. 2014, Zainuddin et al. 2010, Rahayu, A. Y. S., \& Fitriati, R. 2013, Sherman et al. 2008, Schlaegel, 2013). 
Locus of control orientation has been explored in various contexts that revealed different individual levels and sources of impacts, (Bernhofer, L., \& Han, Z. 2014, p. 129). Mueller and Thomas (2001), for example, found an increased likelihood of internal locus of control orientation in individualistic cultures, which confirms their argument that culture generally conditions a potential for entrepreneurship. Gürol, Y., \& Atsan, N. (2006) states that it is believed that entrepreneurs have an internal locus of control. Entrepreneurs searching for opportunities and taking an innovative attitude are also expected to have the capacity to control the events in their lives, or in other words, have locus of inner control (Bernhofer, L., \& Han, Z. 2014, Ajzen, 2002, Bernhofer, L., \& Han, Z. 2014, p. 129, Mueller and Thomas 2001, Gürol, Y., \& Atsan, N. 2006).

Harris, M. L., \& Gibson, S. G. (2008) states that no differences were evident based on the demographic variables of gender, age, parent(s) as entrepreneur(s), work experience, years of work experience, grade expected, or degree requirement. He indicates that no link between demographic characteristics and entrepreneurial attitudes of college students, another study found that male African American college students had a more positive attitude toward entrepreneurship than their female counterparts (Mohamed et al. 2012, Harris, M. L., \& Gibson, S. G. 2008, Liñán, F., \& Chen, Y. 2009, Haus et al. 2013, Dabic 2012, Johansen, V. 2013, Majumdar, S., \& Varadarajan, D. 2013, Tae Jun Bae et al. 2014, Barbosa et al. 2008, Zhang et al.2014)

In the IT entrepreneurial context, CSE is related to innovation self-efficacy, which refers to entrepreneurs' technology and business innovations (Lourenco et al. 2013, Chen, L. 2013, O’Boyle et al. 2012, Vij, V., \& Ball, S. 2009).

Even though these factors were developed in various empirical studies, there are other contextual factors that may influence directly or indirectly the entrepreneurial intentions.

We suggest that the future researchers may compare the contextual factors of entrepreneurial intentions among developed and developing countries.

This work is supported by the cultural school in strategy with the main principles of its own culturally school catechism: The development of the strategy is a process of social interaction, based on the beliefs and convictions shared by the members of the company; An individual acquires these beliefs by a process of acculturation or socialization largely tacit and non-verbal, although sometimes reinforced by a more formal indoctrination; The members of the company, therefore, can only partially describe the beliefs that underpin their culture, the origins and explanations can remain in the dark; It follows that the strategy essentially takes the form of a perspective, more than one position; Culture and above ideology encourage less strategic change that the perpetuation of the existing strategy; at best, they tend to move positions within the overall strategic business perspective with this cultural principals the created ventures can sustain and get more profitable (Mintzberg, H., Ahlstrand, B., \& Lampel, J. 2009).

As it was stated that a firm's culture can be a source of sustainable competitive advantage if that culture is valuable, rare, and imperfectly imitable; as a researcher on youth entrepreneurship, I will make sure that my research is original, of actuality, and useful to society. I will make my contribution to the existing body of knowledge a unique. I will always have competitive spirit and look for innovations. As we have seen that one key is for top managers to accept as a major premise in any company's culture the importance of flexibility and innovation. I will always be ready to make change where needed and look for other researchers' works to learn from them. 
With regards to "Ecole de positionnement", Mintzberg, H., Ahlstrand, B., \& Lampel, J. (2009). State that the roots of social order are in our heads, where we possess the instinctive capacities for creating not a perfectly harmonious and virtuous society, but a better one than we have at present. We must build our institutions in such a way that they draw out those instincts. Pre-eminently this means the encouragement of exchange between equals. Just as trade between countries is the best recipe for friendship between them, so exchange between enfranchised and empowered individuals is the best recipe for cooperation.

Finally, in the entrepreneurial school of Mintziberg, we Nous leant that we do not have to concentrate much the development process of the strategy exclusively to the only one leader but to underline the importance of his/ her spirit state and his/ her deep process of thinking: intuition, judgement, wisdom, experience and perspicacity. Thus, it is good to recognize that the stategy is associated to the image and orientation of the visionary.

\section{REFERENCES}

[1] Ajzen, I. (2002) 'Perceived behavioral control, self-efficacy, locus of control, and the theory of planned behavior', Journal of Applied Social Psychology, Vol. 32, No. 4, pp.665-683.*

[2] Barbosa, S.D., Kickul,J., \&Smith, B. R.(2008).THEROAD LESS INTENDED: INTEGRATINGENTREPRENEURIAL COGNITION AND RISK IN ENTREPRENEURSHIP EDUCATION. Journal of Enterprising Culture, 16(4), 411.*

[3] Bernhofer, L., \& Han, Z. (2014). Contextual factors and their effects on future entrepreneurs in china: A comparative study of entrepreneurial intentions. International Journal of Technology Management, 65(1-2), 125.

[4] Chen, L. (2013). IT entrepreneurial intention among college students: An empirical study. Journal of Information Systems Education, 24(3), 233-243**

[5] Dabic, M., Daim, T., Bayraktaroglu, E., Novak, I., \& Basic, M. (2012). Exploring gender differences in attitudes of university students towards entrepreneurship. International Journal of Gender and Entrepreneurship, 4(3), 316-336.*

[6] Daghbashyan, Z., \& Harsman, B. (2014). University choice and entrepreneurship. Small Business Economics, 42(4), 729-746.*

[7] Ertuna, Z.I. and Gurel, E. (2011) 'The moderating role of higher education on entrepreneurship', Education + Training, Vol. 53, No. 5, pp.387-402**

[8] Fayolle, A., \& Gailly, B. (2015). The impact of entrepreneurship education on entrepreneurial attitudes and intention: Hysteresis and persistence. Journal of Small Business Management, 53(1), 75-93.*

[9] Fayolle, A., \& Liñán, F. (2014). The future of research on entrepreneurial intentions. Journal of Business Research, 67(5), 663-666.*

[10] Fayolle, A., Gailly, B., \& Lassas-Clerc, N. (2006). Assessing the impact of entrepreneurship education programmes: A new methodology. Journal of European Industrial Training, 30(9), 701-720.*

[11] Fayolle, A., Gailly, B., \& Lassas-Clerc, N. (2006). Assessing the impact of entrepreneurship education programmes: A new methodology. Journal of European Industrial Training, 30(9), 701-720. 
[12] Ghazali, Z., Ibrahim, N. A., \& Zainol, F. A. (2013). Factors affecting entrepreneurial intention among UniSZA students. Asian Social Science, 9(1), 85-93.

[13] Giacomin, O., Janssen, F., Pruett, M., Shinnar, R. S., Llopis, F., \& Toney, B. (2011). Entrepreneurial intentions, motivations and barriers: Differences among american, asian and european students. International Entrepreneurship and Management Journal, 7(2), 219-238.*

[14] Gürol, Y., \& Atsan, N. (2006). Entrepreneurial characteristics amongst university students: Some insights for entrepreneurship education and training in turkey. Education \& Training, 48(1), 25-38.*

[15] Harris, M. L., \& Gibson, S. G. (2008). Examining the entrepreneurial attitudes of US business students. Education \& Training, 50(7), 568-581.

[16] Haus, I., Steinmetz, H., Isidor, R., \& Kabst, R. (2013). Gender effects on entrepreneurial intention: A meta-analytical structural equation model. International Journal of Gender and Entrepreneurship, 5(2), 130-156.

[17] Hofstede, G. (2001). Culture's consequences: Comparing values, behaviors, institutions, and organizations across nations. Thousand Oaks, CA: Sage.*

[18] Iacobucci, D., \& Micozzi, A. (2012). Entrepreneurship education in italian universities: Trend, situation and opportunities. Education \& Training, 54(8), 673-696.*

[19] Iakovleva, T. A., Kolvereid, L., Gorgievski, M. J., \& Sørhaug, Ø. (2014). Comparison of perceived barriers to entrepreneurship in eastern and western european countries. International Journal of Entrepreneurship and Innovation Management, 18(2-3), 115.*

[20] Iakovleva, T., Kolvereid, L., \& Stephan, U. (2011). Entrepreneurial intentions in developing and developed countries. Education \& Training, 53(5), 353-370.

[21] Johansen, V. (2013). Entrepreneurship education and start-up activity: A gender perspective. International Journal of Gender and Entrepreneurship, 5(2), 216-231.*

[22] Jorge, J. D., Leopoldo, L. C., \& María, S. T. (2012). The effect of business and economics education programs on students' entrepreneurial intention. European Journal of Training and Development, 36(4), 409-425.*

[23] Leung, K., Lo, C., Sun, H., \& Wong, K. (2012). FACTORS INFLUENCING ENGINEERING STUDENTS' INTENTION TO PARTICIPATE IN ON-CAMPUS ENTREPRENEURIAL ACTIVITIES. Journal of Entrepreneurship Education, 15, 1-19.*

[24] Leung, K., Lo, C., Sun, H., \& Wong, K. (2012). FACTORS INFLUENCING ENGINEERING STUDENTS' INTENTION TO PARTICIPATE IN ON-CAMPUS ENTREPRENEURIAL ACTIVITIES. Journal of Entrepreneurship Education, $15,1-19 . *$

[25] Lin, J., \& Nabergoj, A. S. (2014). A RESOURCE-BASED VIEW OF ENTREPRENEURIAL CREATIVITY AND ITS IMPLICATIONS TO ENTREPRENEURSHIP EDUCATION. Economic and Business Review for Central and South - Eastern Europe, 16(2), 163-183,218-219.*

[26] Liñán, F., \& Chen, Y. (2009). Development and cross-cultural application of a specific instrument to measure entrepreneurial intentions. Entrepreneurship, 33(3), 593-618. 
[27] Liñán, F., Fernández, J., \& Romero, I. (2013). Necessity and opportunity entrepreneurship: The mediating effect of culture. Revista de Economía Mundial, 33, 21-47.*

[28] Liñán, F., Urbano, D., \& Guerrero, M. (2011). Regional variations in entrepreneurial cognitions: Start-up intentions of university students in Spain. Entrepreneurship and Regional Development, 23(3\&4), 187-215.*

[29] Lourenco, F., Jones, O., \& Jayawarna, D. (2013). Promoting sustainable development: The role of entrepreneurship education. International Small Business Journal, 31(8), 841-865.*

[30] Lussier, R. N (2011). Research methods and statistics for business. Waveland Press (Long Grove, IL,)*

[31] Luthje, C. \& N. Franke (2003). The 'making' of an entrepreneur: testing a model of entrepreneurial intent amongst engineering students at MIT. R \& D Management, 33(2), 135-148.*

[32] Luthje, C. \& N. Franke (2003). The 'making' of an entrepreneur: testing a model of entrepreneurial intent amongst engineering students at MIT. R \& D Management, 33(2), 135-148.*

[33] Majumdar, S., \& Varadarajan, D. (2013). Students' attitude towards entrepreneurship: Does gender matter in the UAE? Foresight : The Journal of Futures Studies, Strategic Thinking and Policy, 15(4), 278-293.*

[34] Martinez, D., Mora, J., \& Vila, L. E. (2007). Entrepreneurs, the self-employed and employees amongst young european higher education graduates. European Journal of Education, 42(1), 99-117.*

[35] Mintzberg, H., Ahlstrand, B., \& Lampel, J. (2009). Safari en pays stratégie: l'exploration des grands courants de la pensée stratégique. Pearson.*

[36] Mohamed, Z., Rezai, G., Mad, N. S., \& Muhammad Mu'az Mahmud. (2012). Enhancing young graduates' intention towards entrepreneurship development in malaysia. Education \& Training, 54(7), 605-618.*

[37] Moriano, J. A., Gorgievski, M., Laguna, M., Stephan, U., \& Zarafshani, K. (2012). A cross-cultural approach to understanding entrepreneurial intention. Journal of Career Development, 39(2), 162-185.*

[38] Moriano, J. A., Gorgievski, M., Laguna, M., Stephan, U., \& Zarafshani, K. (2012). A cross-cultural approach to understanding entrepreneurial intention. Journal of Career Development, 39(2), 162-185.

[39] Mueller, S.L. and Thomas, A.S. (2001) 'Culture and entrepreneurial potential: a nine country study of locus of control and innovativeness', Journal of Business Venturing, Vol. 16, No. 1, pp.51-75.*

[40] Nabi, G. and Linan, F. (2011) 'Graduate entrepreneurship in the developing world: intentions, education and development', Education + Training, Vol. 53, No. 5, pp.325-334.*

[41] O’Boyle, E. H., Jr, Pollack, J. M., \& Rutherford, M. W. (2012). Exploring the relation between family involvement and firms' financial performance: A meta-analysis of main and moderator effects. Journal of Business Venturing, 27(1), 1 . $^{*}$

[42] Oosterbeek, H., van Praag, M., \& Ijsselstein, A. (2010). The impact of entrepreneurship education on entrepreneurship skills and motivation. European Economic Review, 54(3), 442-454.*

[43] Ozgen, E., \& Minsky, B. D. (2013). WHY SOME COLLEGE STUDENTS ENGAGE IN ENTREPRENEURIAL ACTIVITIES WHILE OTHERS DO NOT. Journal of Entrepreneurship Education, 16, 45-58.* 
[44] Packham, G., Jones, P., Miller, C., Pickernell, D., \& Brychan, T. (2010). Attitudes towards entrepreneurship education: A comparative analysis. Education \& Training, 52(8), 568-586.*

[45] Pittaway, L. and Cope, J. (2007). Entrepreneurship education: A systematic review of the evidence. International Small Business Journal 25:479-510.*

[46] Pruett, M. (2012). Entrepreneurship education: Workshops and entrepreneurial intentions. Journal of Education for Business, 87(2), 94.

[47] Rahayu, A. Y. S., \& Fitriati, R. (2013). Change in student mindset toward entrepreneur an action research. Bisnis \& Birokrasi, 20(2), 98-105.*

[48] Schlaegel, C., He, X., \& Engle, R. L. (2013). The direct and indirect influences of national culture on entrepreneurial intentions: A fourteen nation study. International Journal of Management, 30(2), 597-609.

[49] Schlee, R. P., Stewart, R., \& Summers, D. (2013). TRAINING STUDENTS FOR ENTREPRENEURIAL ACTIVITIES: LESSONS FROM A SOCIAL VENTURE PLAN COMPETITION. Journal of Entrepreneurship Education, 16, 125-138.*

[50] Shapero A (1982) Social dimensions of entrepreneurship. In: Kent CA et al (eds) The encyclopedia of entrepreneurship. Englewood Cliffs, Prentice-Hall, pp 72-89*

[51] Sherman, P. S., Sebora, T., \& Digman, L. A. (2008). EXPERIENTIAL ENTREPRENEURSHIP IN THE CLASSROOM: EFFECTS OF TEACHING METHODS ON ENTREPRENEURIAL CAREER CHOICE INTENTIONS. Journal of Entrepreneurship Education, 11, 29-42**

[52] Shinnar, R. S., Giacomin, O., \& Janssen, F. (2012). Entrepreneurial perceptions and intentions: The role of gender and culture. Entrepreneurship, 36(3), 465-493.*

[53] Simon Mosey, Hannah Noke \& Martin Binks (2012).The influence of human and social capital upon the entrepreneurial intentions and destinations of academics. Technology analysis \& strategic management [0953-7325] An.:2012 Vol. :24 iss :9 pg :893*

[54] Smith, I. H., \& Woodworth, W. P. (2012). Developing social entrepreneurs and social innovators: A social identity and self-efficacy approach. Academy of Management Learning \& Education, 11(3), 390.*

[55] Solesvik, M. Z. (2013). Entrepreneurial motivations and intentions: Investigating the role of education major. Education \& Training, 55(3), 253-271.

[56] St-Jean, É., Nafa, A., Tremblay, M., Janssen, F., Baronet, J., \& Loué, C. (2014). Entrepreneurial intentions of university students: An international comparison between african, european and canadian students. International Journal of Entrepreneurship and Innovation Management, 18(2-3), 95.

[57] Tae Jun Bae, Shanshan Qian, Chao Miao \& James O. Fiet (2014).The Relationship between entrepreneurship educatuion) and all (entrepreneurial intentions: A Meta - analytic review. DOI: 10.1111/etap.12095*

[58] Vij, V., \& Ball, S. (2009). Exploring the impact of entrepreneurship education on university nonbusiness undergraduates. International Journal of Entrepreneurship and Small Business, 9(1), 86-109.*

[59] Walter, A., Walter, S. G., \& Parboteeah, K. P. (2013). University departments and self-employment intentions of business students: A cross-level analysis. Entrepreneurship, 37(2), 175-200** 
[60] Walter, S. G., \& Dohse, D. (2012). Why mode and regional context matter for entrepreneurship education. Entrepreneurship and Regional Development, 24(9-10), 807-835.*

[61] Watson, T. J. (2013a). Entrepreneurial action and the Euro-American social science tradition: pragmatism, realism and looking beyond 'the entrepreneur'. Entrepreneurship and Regional Development, (25), 16.*

[62] Wurthmann, K. (2014). Business students' attitudes toward innovation and intentions to start their own businesses. International Entrepreneurship and Management Journal, 10(4), 691-711.*

[63]Zahra, S. A., \& Wright, M. (2011). Entrepreneurship's next act. Academy of Management Perspectives, 25(4), 67.83.*

[64]Zainuddin, M. N., \& Mohd Rozaini, M. R. (2010). Assessing “ME generation's” entrepreneurship degree programmes in malaysia. Education \& Training, 52(6), 508-527.*

[65]Zhang, Y., Duysters, G., \& Cloodt, M. (2014). The role of entrepreneurship education as a predictor of university students' entrepreneurial intention. International Entrepreneurship and Management Journal, 10(3), 623-641.

NB: The articles with $(*)$ are the articles which worked on entrepreneurial context but which did not use the Theory of Planned Behavior (TPB)

Citation: Rukundo, S. Friend, Cyeze, M. Emmanuel, Mwambari, Faustin, The Role of Context in Shaping Students Entrepreneurial Intentions, American Research Journal of Humanities and Social Sciences Volume 2, 2016; $p p: 1-18$

Copyright (C) 2016 Rukundo, S. Friend, Cyeze, M. Emmanuel, Mwambari, Faustin, This is an open access article distributed under the Creative Commons Attribution License, which permits unrestricted use, distribution, and reproduction in any medium, provided the original work is properly cited. 